\title{
ORPHAN DRUGS USED FOR TREATMENT IN PEDIATRIC PATIENTS IN THE SLOVAK REPUBLIC
}

\author{
${ }^{1}$ Foltánová, T. $-{ }^{2}$ Konečný, M. $-{ }^{3}$ Hlavatá, A. $-{ }^{4}$ Štepánková, $K$. \\ ${ }^{5}$ Cisárik, $F$. \\ ${ }^{1}$ Comenius University in Bratislava, Faculty of Pharmacy, \\ Department of Pharmacology and Toxicology \\ ${ }^{2}$ Department of Clinical Genetics, St. Elizabeth Cancer Institute, Bratislava \\ ${ }^{3} 2^{\text {nd }}$ Department of Pediatrics, UniversityChildren'sHospital, Bratislava \\ ${ }^{4}$ Slovak Cystic Fibrosis Association, Košice \\ ${ }^{5}$ Department of Medical Genetics, Faculty Hospital, Žilina
}

\begin{abstract}
Due to the enormous success of scientific research in the field of paediatric medicine many once fatal children's diseases can now be cured. Great progress has also been achieved in the rehabilitation of disabilities. However, there is still a big group of diseases defined as rare, treatment of which has been traditionally neglected by the drug companies mainly due to unprofitability.

Since 2000 the treatment of rare diseases has been supported at the European level and in 2007 paediatric legislation was introduced. Both decisions together support treatment of rare diseases in children.

In this paper, we shortly characterise the possibilities of rare diseases treatment in children in the Slovak republic and bring the list of orphan medicine products (OMPs) with defined dosing in paediatrics, which were launched in the Slovak market. We also bring a list of OMPs with defined dosing in children, which are not available in the national market. This incentive may help in further formation of the national plan for treating rare diseases as well as improvement in treatment options and availability of rare disease treatment in children in Slovakia.
\end{abstract}

Key words: Orphan drugs -Paediatric regulation - Availability - Accessibility

\section{INTRODUCTION}

If patients are children, it is always complicated. It is even more when children have one of 7000 rare diseases for which treatment is hard to find. Developing treatments for rare conditions is generally an unprofitable effort. In treating paediatric patients, physicians 
and hospitals are often limited by availability of devices or drugs that have not been optimized for the treatment of children. Approximately $80 \%$ of rare diseases has identified genetic origins, and affect between $3 \%$ and $4 \%$ of births. Symptoms of some rare diseases may appear at birth or in childhood, including spinal muscular atrophy, lysosomal storage disorders, alkaptonuria, patent ductus arteriosus (PDA), familial adenomatous polyposis (FAP) and cystic fibrosis but more than half of rare diseases appear during adulthood, such as renal cell carcinoma, glioma and acute myeloid leukaemia. Fewer than 1,000 diseases benefit from even minimal amounts of scientific knowledge. These tend to be the rare diseases that occur most frequently $[1,2]$.

The orphan drug legislation is summarized in two directives, 141/2000 and 847/2000, which support orphan drug development as a wheel of research in rare diseases [3, 4].

The Paediatric Regulation came into force in the European Union (EU) on 26 January 2007. It is summarised in the following legislations: Regulation (EC) No 1901/2006 of the European Parliament and of the Council of 12 December 2006 on medicinal products for paediatric use and Regulation (EC) No 1902/2006, an amending regulation in which changes to the original text were introduced relating to decision procedures for the European Commission. The main objective is to improve the health of children in Europe by [5]:

- facilitating the development and availability of medicines for children aged 0 to 17 years;

- ensuring that medicines for use in children are of high quality, ethically researched and authorised appropriately;

- improving the availability of information on the use of medicines for children.

According to these incentives the research and the marketing authorisation of OMPs for rare diseases in children are supported at the European level mainly due to insufficient availability and low accessibility. However, OMPs face several problems at the national level. In Slovakia the situation is not different and thus also not if paediatrics is taken into account.

\section{METHODS}

OMPs for children connect two marginalised topics: rare diseases and pharmacotherapy of children. Both of them became priorities of European health policy. We decided to bring more information about the possibilities of rare diseases treatment in children in the SR. The list of OMPs directly available in the SR was obtained from the categorisation list, provided by the Slovak Ministry of Health [6]. Further we used the SPC of all OMPs which were launched in the Slovak market till the end of March 2012. This was obtained from the website of the European Medicine agency [7]. Just for the purpose of this paper we consider OMPs as OMPs for children, if the dosing in children was defined in the SPC. 


\section{RESULTS AND DISCUSSION}

Currently in the Slovak republic market, there are 26 OMPs, out of 62 OMPs $(41 \%)$ authorised in the EU. The dosing in paediatrics is defined in 13 OMPs $(50 \%)$, mainly from ATC classes A16 (6 out of 13, 46\%) and L01 (2 out of 13, 15\%). Other ATC classes are H01, C02, G04, N03 and V03, all presented with one OMP. In table 1 we present all OMPs launched in the Slovak market which have defined dosing for children, together with their ATC codes, main indications as well as routes of administration.

The route of administration is of special importance in paediatrics. Most of the OMPs in the SR are administered per os. Of the ATC class A16 miglustat (ZAVESCA) and saptopterin (KUVAN) are available as tablets. The proper route of administration varies with the age of the child. Peroral administration is of significant benefit; however, in new born children, it is complicated. Lack of information about ethiopathogenesis of rare diseases, their variability and the severity complicate the situation. Many of the rare diseases require innovative technologies for the research and development of OMPs. However in rare diseases no other sufficient treatment exists.

To inform clinicians of the gaps in the treatment of rare conditions in children, in Table 2 we list OMPs, with defined dosing in paediatrics, which are not available in the SR. Most of the OMPs in the SR are administered per oral, whereas OMPs not available in the SR are administered parentally. Accidentally the mainly represented are ATC class L01 (7 out of 20,35\%) and ATC class A16 (6 out of 20,30\%), thus corresponding with the fact that oncologic and metabolic diseases are the most fast accelerating fields also in rare diseases [8]. ATC classes as B01, B02 and C02 don't have OMP indicated for children. Low number of OMP launched in the SR, even when use in paediatrics, is taken into account could be caused mainly by missing information about the prevalence of patients with rare diseases. Screening of some inborn diseases is available as phenylketonuria or cystic fibrosis. This is reflected with relatively fast launching of saptopterin (KUVAN) at the Slovak market $[9,10]$. However antibiotics (ATC class J) for cystic fibrosis are distributed at patients named basis, which is mainly administratively but as well as time demanding [11].

Adopting the potential of patient registries may help to understand not only the natural history of rare diseases and their pathophysiology but also motivate the pharmaceutical companies to launch their OMP at the Slovak market. National support of rare diseases, active national plan for rare diseases as well as clear health policy may be other advantages, attracting the OMP pharmaceutical companies [12].

There are several ways how to regulate the use of OMP. These are also depending on the national health policy of every member state. In the SR the prescription is usually restricted by the specialisation of the doctor as well as institutions. In figure 1 the spectrum of OMP reflected in the qualification of the doctor, who is empowered to prescribe OMP in children is presented. More specialists could prescribe the same OMP. All the drugs for metabolic diseases from ATC class A could be prescribed only by paediatrics, others are limited for specialists as neurologists, cardiologists or others, treating children. Mostly represented are haematologists (8 of 12 in SR available OMP) and oncologists (8 of 12 in SR available OMP). 
Also this problem could be solved by precise formulation of National plan for rare diseases as well as creation of Centres of expertise. These would define several material, qualification and financial limits to selected health care units and thus allow highly specialised, time and financially saving health care for patients with rare diseases, independently on the rarity of the disease.

Of high importance is also interdisciplinary review process consistent and transparent, with clear communication between regulators and drug makers.

Table 1 OMPs used in paediatrics available in the $\mathrm{SR}(\mathrm{N}=13)$

\begin{tabular}{|c|c|c|c|c|}
\hline ATC code & Substance & Drug & Indication & $\begin{array}{l}\text { Route of } \\
\text { administration }\end{array}$ \\
\hline A16AB04 & Agalzidase beta & FABRAZYME & Fabry Disease & i.v. \\
\hline A16AB05 & Laronidase & $\begin{array}{l}\text { ALDURAZYM } \\
\text { E }\end{array}$ & Mucopolysaccharidosis I & i.v. \\
\hline A16AB07 & Aglucosidase & NAGLAZYME & Mucopolysaccharidosis VI & i.v. \\
\hline A16AB08 & Galsulfase & MYOZYME & $\begin{array}{l}\text { Glycogen Storage Disease } \\
\text { Type II }\end{array}$ & i.v. \\
\hline A16AX06 & Miglustat & ZAVESCA & $\begin{array}{l}\text { Gaucher Disease; Niemann- } \\
\text { Pick Diseases }\end{array}$ & p.o. \\
\hline A16AX07 & Sapropterin & KUVAN & Hyperfenylalaninemia & p.o. \\
\hline C02KX01 & Bosentan & TRACLEER & $\begin{array}{l}\text { Pulmonary arterial } \\
\text { hypertension }\end{array}$ & p.o. \\
\hline G04BE03 & Sildenafil & REVATIO & $\begin{array}{l}\text { Pulmonary arterial } \\
\text { hypertension }\end{array}$ & p.o. \\
\hline H01AC03 & Mecasermin & INCRELEX & Laron syndrome & i.v. \\
\hline L01XE01 & Imatinib & GLIVEC & CML in children & p.o. \\
\hline L01XX23 & Mitotan & LYSODREN & Adrenal cortical carcinoma & p.o \\
\hline N03AF03 & Rufinamid & INOVELON & Lennox Gastaut syndrome & p.o. \\
\hline V03AC03 & Deferasirox & EXJADE & Fe overload & p.o. \\
\hline
\end{tabular}

Table 2 OMPs used in paediatrics not available in the SR (not available in the SR) (n=20)

\begin{tabular}{lllll}
\hline ATC code & OMP & OMP & Main indication & \multicolumn{1}{c}{$\begin{array}{l}\text { Route of } \\
\text { administration }\end{array}$} \\
\hline A16AA05 & Carglumic acid & CARBAGLU & hyperammonaemia & p.o. \\
\hline A16AA06 & Betaine anhydrous & CYSTADANE & homocystinuria, & p.o. \\
\hline A16AB09 & Idursulfase & ELAPRASE & $\begin{array}{l}\text { Mucopolysaccharidosis II } \\
\text { (Hunter syndrome) }\end{array}$ & i.v. \\
\hline A16AX04 & Nitisinone & ORFADIN & Hereditary tyrosinaemia type 1 & p.o. \\
\hline A16AB10 & Velaglucerase & VPRIV & Gaucher disease type 1 & i.v. \\
\hline A16AX05 & $\begin{array}{l}\text { Zinc acetate } \\
\text { dehydrate }\end{array}$ & WILZIN & Wilson's disease & p.o. \\
\hline C01EB16 & Ibuprofen & PEDEA & patent ductus arteriosus & i.v. \\
\hline J01GB01 & Tobramycin & TOBI & Respiratory tract infections in & Inhal. \\
& PODHALER fibrosis & Acute lymphoblastic leukaemia & i.v. \\
\hline L01BB07 & Nelarabine & ATRIANCE & essential thrombocythaemia(ET) & p.o. \\
\hline
\end{tabular}




\begin{tabular}{|c|c|c|c|c|}
\hline L01XX05 & Hydroxycarbamide & SIKLO & Sickle Cell Syndrome & p.o. \\
\hline L01AB01 & Busulfan & BUSILVEX & $\begin{array}{l}\text { conditioning treatment prior to } \\
\text { conventional haematopoietic } \\
\text { progenitor cell transplant }\end{array}$ & i.v. \\
\hline L01BB06 & Clofarabine & EVOLTRA & $\begin{array}{l}\text { acute lymphoblastic leukaemia } \\
\text { (ALL) }\end{array}$ & i.v. \\
\hline L01AC01 & Thiotepa & TEPADINA & $\begin{array}{l}\text { haematopoietic progenitor cell } \\
\text { transplantation (HPCT) in } \\
\text { haematological diseases }\end{array}$ & i.v. \\
\hline L01XE10 & Everolimus & VOTUBIA & $\begin{array}{l}\text { subependymal giant cell } \\
\text { astrocytoma (SEGA) }\end{array}$ & p.o. \\
\hline L03AX15 & Mifamurtid & MEPACT & $\begin{array}{l}\text { high-grade resectable non- } \\
\text { metastatic osteosarcoma }\end{array}$ & i.v. \\
\hline L04AC08 & Rilonacept & RILONACEPT & $\begin{array}{l}\text { Cryopyrin-Associated Periodic } \\
\text { Syndromes(CAPS) with severe } \\
\text { symptoms }\end{array}$ & i.v. \\
\hline L04AA25 & Pegvisomat & SOLIRIS & $\begin{array}{l}\text { Paroxysmal nocturnal } \\
\text { haemoglobinuria }(\mathrm{PNH}) \\
\text { Atypical haemolytic uremic } \\
\text { syndrome (aHUS) }\end{array}$ & i.v. \\
\hline N03AX17 & Stiripentol & DIACOMIT & $\begin{array}{l}\text { severe myoclonic epilepsy in } \\
\text { infancy (SMEI, Dravet's } \\
\text { syndrome) }\end{array}$ & p.o. \\
\hline N06BC01 & Caffeine citrate & PEYONA & $\begin{array}{l}\text { primary apnoea of premature } \\
\text { newborns }\end{array}$ & i.v. \\
\hline
\end{tabular}

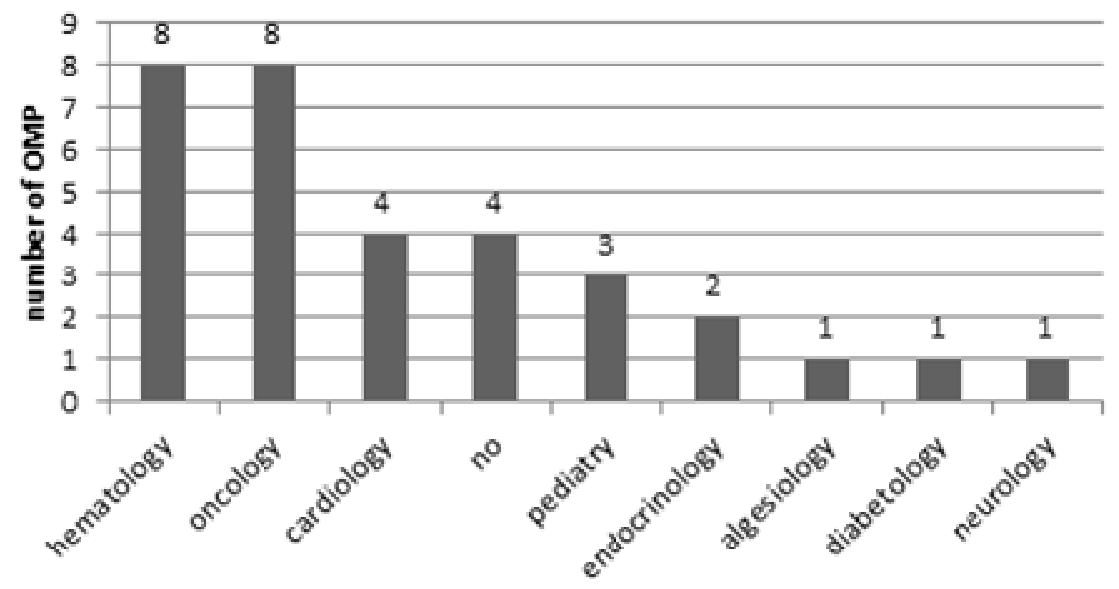

prescribtion restriction

Figure 1.Classification of OMP directly available in the SR according to the specialisation of the doctor 


\section{CONCLUSION}

Both OMP legislative as well as the paediatric regulation are driven and supported at the European level. Together they stimulate high-quality research and provide information about rare diseases and their treatment possibilities. However the treatment of rare disease stresses the necessity to improve the national health policy as one of the fundamental steps to increase availability of OMP as well as rare diseases treatment in general. This is even more important in the field of paediatric medicine. For the pharmaceutical companies the Slovak republic presents small market. This is a constant variable and could be understand as disadvantage, supported by our results. More OMP with defined dosing in children are still missing than directly available in the SR.

\section{REFERENCES}

1. Orphan drugs and rare diseases at glance Available at http://www.ema.europa.eu/docs/en_GB/document_library/Other/2010/01/WC5000 69805.pdf [last access verified 20/3/2012]

2. Hoppu, K.: Paediatric clinical pharmacology - at the beginning of new era, Eur J Clin Pharmacol, 2008, 64, p. 201-205

3. Regulation (EC) No $141 / 2000$ of the European parliament and of the council. Off J Eur Commun, 43, 2000, L18, p. 1-5.

4. Regulation (EC) No 847/2000, Off J EurCommun, 43, 2000, L103, p. 5-8.

5. Regulation (EC) No 1901/2006 of the European Parliament and of the Council;on medicinal products for paediatric use and amending Regulation (EEC) No 1768/92, Directive 2001/20/EC, Directive 2001/83/EC and Regulation (EC) No 726/2004- of 12 December 2006. available at http://ec.europa.eu/health/files/eudralex/vol1/reg_2006_1901/reg_2006_1901_en.pdf [last access verified 20/3/2012]

6. The Ministry of Health Slovakia Website. http://www.health.gov.sk/?zoznamkategorizovanych-

liekovhttp://www.ema.europa.eu/ema/index.jsp?curl=pages/medicines/landing/orphan_searc h.jsp\&murl=menus/medicines/medicines.jsp\&mid $=$ WC0b01ac058001d12b\&startLetter $=$ Vie w\%20all\&keyword=Enter\%20keywords\&searchType=Active\%20Substance $\&$ jsenabled $=$ tru e\&alreadyLoaded $=$ true $\&$ status $=$ Positive $\&$ page $\mathrm{No}=3$

7. http://www.ema.europa.eu/ema/index.jsp?curl=\%2Fpages $\% 2$ Fmedicines $\% 2$ Flanding $\% 2$ Fepa r_search.jsp\&mid=WC0b01ac058001d124\&searchTab=searchByAuthType\&alreadyLoaded $=$ true $\&$ isNewQuery $=$ true $\&$ status $=$ Authorised $\&$ keyword $=$ Enter+keywords\&searchType $=$ nam e\&taxonomyPath $=\&$ treeNumber $=\&$ searchGenericType $=$ orphan

8. WESTERMARK, K. et al.: European regulation on orphan medicinal products: 10 years of experience and future perspectives. Nature Rev Drug Discov. 2011;10:341-349

9. KUŽELOVÁ, M.: Does European „orphan“ medicinal products legislation help to treat children suffering from rare diseases? (in slovak) Pediatria pre prax. 8, 5, 2007, p. 260-262

10. KUŽELOVÁ, M. - REPICKÁ, L. - ONDRIAŠOVÁ, E. - KOVÁCSOVÁ, B. - MAZÁG, J. -FOLTÁNOVÁ, T.: Is early treatment of patients with rare diseases in Slovak republic really available? (in slovak) Farm Obzor, 79, 8, 2010, p. 223-227.

11. The State Institute for Drug Control Website 
http://www.sukl.sk/sk/databazy-a-servis/databazy/vyhladavanie-v-databaze-registrovanychliekov?page id $=242 \&$ lie nazov $=\&$ lie $\mathrm{kod}=\&$ atc $\mathrm{kod}=\&$ lie $\mathrm{rc}=\&$ atc nazov $=\&$ isk $\mathrm{kod}=0$ \& drz_kod $=\&$ vyd_kod $=0 \& \overline{o r g} \_$kod $=0 \&$ reg_typ_kod $=$ EUO\&in_kat $=I N N \bar{N} E R \& p e d \_i n \bar{d}=A L L \&$ ped_kontraind $=$ ALL [last access verified 20/3/2012]

12. http://ec.europa.eu/pharmaforum/docs/pricing_orphans_en.pdf

Registered: October 2011

Accepted: January 2012
PharmDr. Tatiana Foltánová, $\mathrm{PhD}$

Faculty of Pharmacy

Comenius University

Odbojárov 10

83232 Bratislava

foltanova@fpharm.uniba.sk

\title{
LIEKY NA ZRIEDKAVÉ CHOROBY, POUŽÍVANÉ NA LIEČBU DETSKÝCH PACIENTOV V SLOVENSKEJ REPUBLIKE
}

\author{
${ }^{1}$ Foltánová, T. $-{ }^{2}$ Konečný, M. $-{ }^{3}$ Hlavatá, A. $-{ }^{4}$ Štepánková, K. \\ ${ }^{5}$ Cisárik, $F$. \\ ${ }^{1}$ Univerzita Komenského v Bratislave, Farmaceutická fakulta, \\ Katedra farmakológie a toxikológie, \\ ${ }^{2}$ Oddelenie lekárskej genetiky, Onkologický ústav sv. Alžbety, Bratislava \\ ${ }^{3} 2$. detská klinika Lekárskej fakulty Univerzity Komenského a Detskej fakultnej nemocnice \\ s poliklinikou v Bratislave, Bratislava \\ ${ }^{4}$ Slovenská asociácia cystickej fibrózy, Košice \\ ${ }^{5}$ Oddelenie lekárskej genetiky, NsP, Žilina

\begin{abstract}
Vd’aka vedeckému pokroku v liečbe detských ochorení, mnohé doposial' neliečitel'né detské choroby sa stávajú liečitel'nými. Vel'ký pokrok sa zaznamenal tiež v rehabilitácii porúch. Stále však existuje skupina chorôb, definovaných ako zriedkavé, liečba ktorých bola zo strany farmaceutického priemyslu nedostatočne podporovaná a to najmä kvôli finančnej nerentabilite investovaných prostriedkov. Od roku 2000 liečba zriedkavých chorôb je podporovaná európskou legislatívou a v roku 2007 bola predstavená legislatíva na podporu liečby detských chorôb. Obidve rozhodnutia tak spoločne podporujú liečbu zriedkavých chorôb u detí.

V tejto práci prinášame stručnú charakteristiku liečebných možností zriedkavých chorôb u detí v Slovenskej republike, zoznam liekov na zriedkavé choroby s definovaným dávkovaním u detí, ktoré sú dostupné na slovenskom trhu. Tiež uvádzame zoznam liekov na zriedkavé choroby $\mathrm{s}$ definovaným dávkovaním u detí, ktoré v Slovenskej republike nie sú priamo dostupné. Touto prácou chceme d’alej podporit' rozvoj Národného plánu pre zriedkavé choroby.
\end{abstract}

Acta Fac. Pharm. Univ. Comen., Suppl., 2012, VI, p. 28 - 34. 